\title{
PENGGUNAAN ABU BATU KARANG SEBAGAI FILLER DAN PASIR BESI SEBAGAI AGREGAT HALUS TERHADAP PARAMETER MARSHALL PADA CAMPURAN ASPAL AC-BC
}

\author{
Said Jalalul Akbar ${ }^{1)}$, Wesli ${ }^{2)}$, Lis Ayu Widari ${ }^{3)}$, Khairil Munawir ${ }^{4)}$ \\ Jurusan Teknik Sipil, Fakultas Teknik, Universitas Malikussaleh \\ email:jaakidani@gmail.com ${ }^{1)}$, wesli@ unimal.ac.id ${ }^{2)}$
}

DOI: http://dx.doi.org/10.29103/tj.v9i2.253

(Received: August 2019 / Revised: August 2019 / Accepted: September 2019)

\begin{abstract}
Abstrak
Campuran beraspal panas adalah kombinasi antara agregat yang dicampur merata dan dilapisi oleh aspal. Bahan penyusun dari campuran AC-BC hampir sama dengan bahan penyusun campuran aspal beton lainnya yaitu agregat halus, agregat kasar, filler dan aspal. Adapun membedakan adalah komposisi gradasi masing-masing lapisan. Penelitian ini membahas mengenai pengaruh penggantian filler dan agregat halus pada perkerasan jalan aspal beton AC-BC. Tujuan dari penelitian ini adalah untuk mengetahui bagaimana pengaruh penggunaan Abu batu karang sebagai Filler dan pasir besi sebagai agregat halus terhadap karakteristik Marshall pada campuran Aspal AC-BC (Asphalt Concrete - Binder Course) menggunakan metode Spesifikasi Umum Bina Marga 2010 Revisi 3. Dari hasil pengujian diperoleh kadar aspal optimum adalah sebesar $6,2 \%$. Variasi benda uji yang digunakan terhadap abu batu karang dan pasir besi adalah 25\%, 50\%, 75\% dan 100\%. Hasil pengujian di laboratorium memperlihatkan bentuk grafik yang naik turun. Peningkatan nilai stabilitas didapat pada variasi penambahan $25 \%, 50 \%, 75 \%$, dan mengalami penurunan pada variasi penambahan $100 \%$ pasir besi dan abu batu karang. Sedangkan nilai Density meningkat pada variasi $100 \%$. VMA, VIM dan Flow menurun pada variasi 50\% dan $100 \%$. Sedangkan VFA, MQ terjadi peningkatan yang tidak terlalu signifikan pada variasi 100\%, maka dapat disimpulkan bahwa variasi penambahan abu batu karang dan dan pasir besi sebagai pengganti filler dan penganti agregat halus memenuhi spesifikasi umum Bina Marga 2010 Revisi 3, sehingga layak untuk digunakan pada campuran aspal (AC-BC).
\end{abstract}

Kata Kunci: Batu karang, pasir besi, filler, agregat halus, parameter Marshall

\begin{abstract}
Hot asphalt mixture is a combination of aggregates that are mixed evenly and coated with asphalt. The ingredients of the AC-BC mixture are almost the same as those of other concrete asphalt mixers, namely fine aggregates, coarse aggregates, fillers and asphalt. The difference is the gradation composition of each layer. This study discusses the effect of replacing filler and fine aggregate on $\mathrm{AC}-\mathrm{BC}$ asphalt concrete pavement. The purpose of this study was to determine how the influence of the use of rock ash as fillers and iron sand as fine aggregate on the characteristics of Marshall in AC-BC (Asphalt Concrete - Binder Course) mix using the 2010 Revised Bina Marga General Specifications method 3. From the test results the optimum asphalt content was obtained at $6.2 \%$. Variations of the test specimens used for rock ash and iron sand are $25 \%, 50 \%, 75 \%$ and $100 \%$. The results of testing in the laboratory show graphical form that fluctuates. The increase in the stability value was found in variations of the addition of $25 \%, 50 \%, 75 \%$, and decreased in the variation of the addition of $100 \%$
\end{abstract}

Penggunaan Abu Batu Karang Sebagai Filler Dan Pasir Besi Sebagai Agregat Halus Terhadap Parameter Marshall Pada Campuran Aspal Ac-Bc - Said Jalalul Akbar, 
iron sand and rock ash. While the Density value increases at a variation of $100 \%$. VMA, VIM and Flow decrease at variations of $50 \%$ and $100 \%$. While VFA, MQ did not increase too significantly at $100 \%$ variation, it can be concluded that the variation of the addition of rock ash and and iron sand as a substitute for filler and fine aggregate substitutes fulfills the 2010 Revised 3 Bina Marga general specifications, making it suitable for use in blends asphalt (AC-BC).

Keywords: Rock, iron sand, filler, fine aggregate, Marshall parameters

\section{Latar Belakang}

Keberadaan jalan raya sangat diperlukan untuk menunjang laju pertumbuhan ekonomi seiring dengan meningkatnya kebutuhan sarana transportasi yang dapat menjangkau daerah-daerah terpencil yang merupakan sentra produksi pertanian (Hendarsin, 2000)

Mutu dari sebuah perkerasan jalan sangat berpengaruh terhadap umur rencana dari jalan tersebut. Mutu perkerasan juga berpengaruh terhadap kelancaran lalu lintas pada daerah/jalan tersebut. Perkerasan akan mempunyai mutu yang baik, apabila perancangan dilakukan dengan baik dan seluruh kamponen utama dalam sistem perkerasan berfungsi dengan baik, oleh karena itu, desain campuran aspal yang digunakan sangat penting dalam memastikan mutu campuran yang baik serta efektif dan mampu mengatasi kerusakan pada jalan.

Salah satu jenis campuran yang digunakan pada umumnya di Indonesia adalah Aspal Beton (Asphalt Concrete). Aspal beton merupakan campuran yang terdiri dari aspal keras sebagai bahan pengikat dan agregat kasar, agregat halus, dan pengisi, dengan cara pencampuran dan pemadatannya dalam kondisi panas dan suhu tertentu. Aspal beton biasanya digunakan untuk lapis permukaan (surface caurse), dan lapis perata (levelling) serta pengikat/antara (Hardiyatmo et al, 2015). Jenis-jenis campuran aspal panas yang sudah digunakan di Indonesia adalah lapis aspal beton (Asphalt Concrete), lapis tipis aspal beton ( Hot Rolled Sheets), lapis tipis aspal pasir (sand sheet).

Dalam penelitian ini digunakan bahan altenatif berupa abu batu karang sebagai Filler dan pasir besi sebagai agregat halus. Batu karang merupakan bahan yang diperoleh dari alam berupa hasil tambang dan juga hasil pemecahan batu yang diperoleh dari sungai yang mengandung kimia berupa $\mathrm{CaO}$, bahan tersebut banyak terdapat di Indonesia diantaranya di Aceh.batu karang mempunyai butiran dengan ukuran yang berbeda dengan kandungan unsur yang berbeda pula. Pasir besi adalah endapan pasir yang mengandung partikel besi (magnetit) yang terdapat di sepanjang pantai, terbentuk karena proses penghancuran oleh cuaca, air permukaan, dan gelombang terhadap batuan asal yang mengandung mineral besi seperti magnetit, ilmenit, dan oksida besi, kemudian terakumulasi serta tercuci oleh gelombang air laut (Bates, R.L. and Jackson, J.A., 1980).

Berdasarkan uraian di atas ingin diketahui apakah ada pengaruh pemakaian abu batu karang sebagai Filler dan pasir besi sebagai agregat halus terhadap parameter Marshall pada campuran aspal AC-WC.

\section{Metode Penelitian}

Untuk memastikan bahwa material yang digunakan telah memenuhi spesifikasi yang telah disyaratkan, maka terlebih dahulu dilakukan pengujian sifat fisis terhadap material yang akan digunakan. Dari hasil pemeriksaan tersebut 
kemudian dibuat beberapa benda uji dari material standar untuk menentukan Kadar Aspal Optimum (KAO). Benda uji dibuat dengan variasi kadar aspal 4,2\%, $4,7 \%, 5,2 \%, 5,7 \%$, dan 6,2\%. Benda uji yang telah disiapkan kemudian diuji dengan menggunakan alat Marshall test untuk mendapatkan Kadar Aspal Optimum. Setelah diperoleh KAO dari hasil uji Marshall yang harus memenuhi spesifikasi umum 2010 revisi 3 (Bina Marga 2010), Kemudian dibuatkan kembali beberapa benda uji dengan penambahan abu batu karang dan pasir besi dalam campuran aspal beton dengan variasi 0\%, 25\%, 50\%, 75\%, 100\%. Benda uji yang telah dicetak dilakukan perendaman selama 24 jam dan selanjutnya dilakukan perendaman dalam waterbath selama 30 menit. Kemudian dilakukan pengujian Marshall yang bertujuan untuk mengetahui nilai stabilitas, flow, dan nilai parameter marshall berupa VMA, VIM, VFA dan $M Q$ (Sukirman, 2003).

Data-data yang diperlukan dalam penelitian ini adalah agregat dan aspal yang diperoleh dari beberapa Stone Cruser terdekat, sedangkan batu karang yang akan digunakan sebagai bahan tambah diperoleh dari gunung dan bukit di sekitaran aceh utara. Semua data yang diperoleh merupakan data sekunder sedangkan data primer dalam penelitian ini dilakukan di laboratorium dengan menggunakan alat marshall.

Beberapa karakteristik yang harus dimiliki oleh aspal adalah Stabilitas yaitu kemampuan dari suatu perkerasan aspal dalam menerima beban lalu lintas tanpa terjadi perubahan bentuk tetap seperti gelombang, alur, bleeding, keawetan atau durabilitas yaitu kemampuan beton aspal untuk menerima repetisi beban lalu lintas seperti berat kendaraan dan gesekan antara roda kendaraan dan permukaan jalan, serta menahan keausan akibat pengaruh cuaca dan iklim, seperti udara, air atau perubahan temperatur (Sukirman, 1999). Kelenturan atau fleksibilitas adalah kemapuan dari beton aspal untuk menyesuaikan diri akibat penurunan (konsolidasi/settlement) dan pergerakan dari pondasi atau tanah dasar, tanpa terjadi retak. Ketahanan terhadap kelelehan (fatigue resistance) adalah suatu kemampuan dari beton aspal untuk menerima lendutan berulang akibat repetisi beban, tanpa terjadinya kelelehan berupa alur dan retak hal ini tejadi karena jika menggunakan kadar aspal yang tinggi. Kekesatan atau tahanan geser (skid resistance) adalah kemampuan permukaan beton aspal terutama pada kondisi basah, memberikan gaya gesek pada roda kendaraan sehingga roda kendaraan tidak tergelincir ataupun slip. Kedap air (permeabilitas) adalah kemampuan beton aspal untuk tidak dapat dimasuki oleh air ataupun udara ke dalam lapisan beton aspal. Air dan udara dapat menyebabkan terjadinya percepatan proses penuaan aspal, dan pengelupasan film/selimut aspal dari permukaan agregat. Tingkat impermebilitas beton aspal berbanding terbalik dengan tingkat durabilitasnya. Mudah dilaksanakan (workbility) adalah kemampuan campuran beton aspal untuk mudah dihamparkan dan dimampatkan. Faktor yang mempengaruhi tingkat kemudahan dalam proses penghamparan dan pemadatan adalah viskositas aspal, kepekaan aspal terhadap perubahan temperatur gradasi serta kondisi agregat (Sukirman, 2003). Adapun agregat yang sesuai dan cukup tersedia masih harus memenuhi beberapa persyaratan yang dipertimbangkan untuk digunakan sesuai kualitas hotmix aspal yang diinginkan. Beberapa persyaratan tersebut anatara lain Ukuran partikel maksimum, Berat jenis, Kekerasan, Absorbsi (penyerapan), Gradasi agregat, Kebersihan atau kandungan lempung, Bentuk partikel dan Kerentanan atau ketahanan terhadap kelembaban.

Penggunaan Abu Batu Karang Sebagai Filler Dan Pasir Besi Sebagai Agregat Halus Terhadap Parameter Marshall Pada Campuran Aspal Ac-Bc - Said Jalalul Akbar, 


\section{Hasil dan Pembahasan}

\subsection{Analisa Hidrologi}

Pemeriksaan sifat fisis dari material yang akan digunakan merupakan salah satu syarat yang harus dipenuhi dalam perencanaan dari sebuah campuran perkerasan lentur jalan raya. Hal tersebut tentu sangat berpengaruh pada baik buruknya hasil dari sebuah campuran yang akan digunakan pada pembuatan perkerasan lentur jalan raya, Dari pemeriksaan sifat fisis yang telah dilakukan diperoleh hasil untuk agregat kasar seperti Tabel 1.

Tabel 1 Hasil pengujian sifat fisis agregat kasar

\begin{tabular}{|c|c|c|c|c|}
\hline \multirow[b]{2}{*}{ No } & \multirow[b]{2}{*}{ Jenis Pengujian } & \multicolumn{2}{|c|}{ Persyaratan } & \multirow[b]{2}{*}{ Hasil } \\
\hline & & $\operatorname{Min}(\%)$ & $\operatorname{Max}(\%)$ & \\
\hline 1 & Berat jenis curah & 2,5 & - & 2,502 \\
\hline 2 & Berat jenis kering permukaan jenuh & 2,5 & - & 2,543 \\
\hline 2 & Berat jenis semu & 2,5 & - & 2,610 \\
\hline 3 & Penyerapan air & & 3 & 1,649 \\
\hline
\end{tabular}

Berdasarkan hasil penelitian dapat dilihat bahwa hasil uji berat jenis agragat kasar telah memenuhi dan sesuai dengan Spesifikasi Bina Marga 2010 dan dapat diasumsikan bahwa hasil pengujian agregat kasar tersebut telah memenuhi syarat dan dapat digunakan untuk penelitian. Kemudian dilakukan pengujian sifat-sifat fisis agregat halus, maka didapatkan hasil yang disajikan pada Tabel 2.

Tabel 2 Hasil pengujian sifat fisis agregat halus

\begin{tabular}{rlrrr}
\hline \multirow{2}{*}{ No } & \multicolumn{1}{|c}{ Jenis Pengujian } & \multicolumn{2}{c}{ Persyaratan } & \multirow{2}{*}{ Hasil } \\
\cline { 3 - 4 } & & Min $(\%)$ & Max $(\%)$ & \\
\hline 1 & Berat jenis curah & 2,5 & - & 2,542 \\
\hline 2 & Berat jenis kering permukaan jenuh & 2,5 & - & 2,6 \\
\hline 2 & Berat jenis semu & 2,5 & - & 2,697 \\
\hline 3 & Penyerapan air & & 3 & 2,25 \\
\hline
\end{tabular}

Berdasarkan hasil penelitian dapat dilihat bahwa hasil uji berat jenis agragat halus telah memenuhi dan sesuai dengan Spesifikasi Bina Marga 2010 dan layak digunakan untuk penelitian. Tahapan berikutnya dilakukan pengujian untuk menentukan Kadar Aspal Optimum (KAO), maka didapatkan nilai parameter Marshall pada setiap variasi kadar aspal. Nilai tersebut disajikan pada Tabel 3.

Tabel 3 Hasil pengujian Marshall untuk menentukan KAO pada benda uji

\begin{tabular}{cccccccc}
\hline \multirow{2}{*}{ No } & \multirow{2}{*}{ Kriteria } & \multirow{2}{*}{ Spesifikasi } & \multicolumn{5}{c}{ Kadar Aspal (\%) } \\
\cline { 4 - 8 } & & & 4,2 & 4,7 & 5,2 & 5,7 & 6,2 \\
\hline 1 & Density & - & 2,246 & 2,268 & 2,287 & 2,298 & 2,322 \\
\hline 2 & VMA & Min 14 & 16,31 & 15,91 & 15,63 & 15,61 & 15,12 \\
\hline 3 & VIM & $3,0-5,0$ & 8,54 & 7,05 & 5,7 & 4,62 & 3,01 \\
\hline 4 & VFA & Min 65 & 47,76 & 55,66 & 63,58 & 70,53 & 80,13 \\
\hline 5 & Stability & Min 800 & 1331,35 & 1521,51 & 1557,07 & 1564,68 & 1805,34 \\
\hline 6 & Flow & $2,0-4,0$ & 5,133 & 6,033 & 4,117 & 4,217 & 3,833 \\
\hline 7 & MQ & Min 250 & 259,096 & 252,657 & 387,199 & 371,049 & 471,341 \\
\hline
\end{tabular}


Berdasarkan hasil parameter Marshall yang didapat pada setiap variasi aspal tersebut selanjutnya di analisis berdasarkan Spesifikasi Bina Marga untuk menentukan kadar aspal yang memenuhi semua parameter Marshall. Hasil tersebut dapat dilihat pada Tabel 4.

Tabel 4 Penentuan Kadar Aspal Optimum Campuran AC-BC

\begin{tabular}{|c|c|c|c|c|c|c|c|}
\hline \multirow{2}{*}{ No } & \multirow{2}{*}{ Kriteria } & \multirow{2}{*}{ Spesifikasi } & \multicolumn{5}{|c|}{ Kadar Aspal (\%) } \\
\hline & & & 4,2 & 4,7 & 5,2 & 5,7 & 6,2 \\
\hline 1 & Density & - & $\bar{z}$ & & & & \\
\hline 2 & VMA & Min 14 & 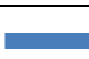 & & & & \\
\hline 3 & VIM & $3,0-5,0$ & & & & & \\
\hline 4 & VFA & Min 65 & & & & & 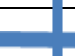 \\
\hline 5 & Stability & Min 800 & & & & & \\
\hline 6 & Flow & $2,0-4,0$ & & & & & \\
\hline 7 & MQ & $\operatorname{Min} 250$ & & & & & \\
\hline
\end{tabular}

Berdasarkan hasil analisis untuk semua parameter Marshall maka didapat nilai Kadar Aspal Optimum (KAO) pada kadar aspal 6,2\%, nilai tersebut lebih besar dari nilai $(\mathrm{Pb})$. Hasil pengujian marshall yang dilakukan pada campuran aspal beton AC-BC dengan campuran abu batu karang sebagai filler dan pasir besi sebagai agregat halus dengan variasi $0 \%, 25 \%, 50 \%, 75 \%$, dan $100 \%$ menggunakan kadar aspal 6,2\% yang didapatkan dari pengujian KAO. Maka di peroleh hasil parameter Marshall setiap variasi filler. Hasil parameter Marshall yang diperoleh disajikan pada Tabel 5

Tabel 5 Hasil Uji Parameter Marshall (Standar Stabilitas)

\begin{tabular}{|c|c|c|c|c|c|c|c|}
\hline \multirow{2}{*}{ No } & \multirow{2}{*}{ Kriteria } & \multirow{2}{*}{ Spesifikasi } & \multicolumn{5}{|c|}{ Kadar Abu batu karang dan pasir besi (\%) } \\
\hline & & & $0 \%$ & $25 \%$ & $50 \%$ & $75 \%$ & $100 \%$ \\
\hline 1 & Density & - & 2,272 & 2,267 & 2,272 & 2,281 & 2,284 \\
\hline 2 & VMA & Min 14 & 15,968 & 16,153 & 15,981 & 15,691 & 15,573 \\
\hline 3 & VIM & $3,0-5,0$ & 5,136 & 5,345 & 5,151 & 4,759 & 4,625 \\
\hline 4 & VFA & Min 65 & 68,043 & 67,333 & 67,925 & 69,689 & 70,338 \\
\hline 5 & Stability & Min 800 & 1368 & 1397 & 1402 & 1419 & 1382 \\
\hline 6 & Flow & $2,0-4,0$ & 3,567 & 3,675 & 3,567 & 3,417 & 3,233 \\
\hline 7 & MQ & $\operatorname{Min} 250$ & 383,79 & 436,07 & 395,98 & 426,88 & 437,46 \\
\hline
\end{tabular}

\subsection{Density}

Dari hasil pengujian Marshall diperoleh nilai density untuk campuran normal adalah sebesar $2,300 \mathrm{gr} / \mathrm{cm}^{3}$, variasi $0 \%$ sebesar $2,272 \mathrm{gr} / \mathrm{cm}^{3}$, variasi $25 \%$ sebesar $2,267 \mathrm{gr} / \mathrm{cm}^{3}$, variasi $50 \%$ sebesar $2,272 \mathrm{gr} / \mathrm{cm}^{3}$, variasi $75 \%$ sebesar $2,281 \mathrm{gr} / \mathrm{cm}^{3}$, dan variasi $100 \%$ sebesar $2,284 \mathrm{gr} / \mathrm{cm}^{3}$. Pengaruh filler abu batu karang dan pasir besi sebagai agregat halus dapat meningkatkan nilai density. nilai density pada variasi $75 \%, 100 \%$ mengalami peningkatan, sedangkan penurunan nilai terjadi pada variasi $0 \%, 25 \%$, dan $50 \%$. Nilai density dipengaruhi oleh berat dari benda uji, meliputi berat benda uji dalam keadaan kering, berat benda uji dalam keadaan lembab dan berat benda uji di dalam air. Nilai density dan hubungan antara nilai density dengan variasi filler dapat dilihat pada Gambar 1 . 


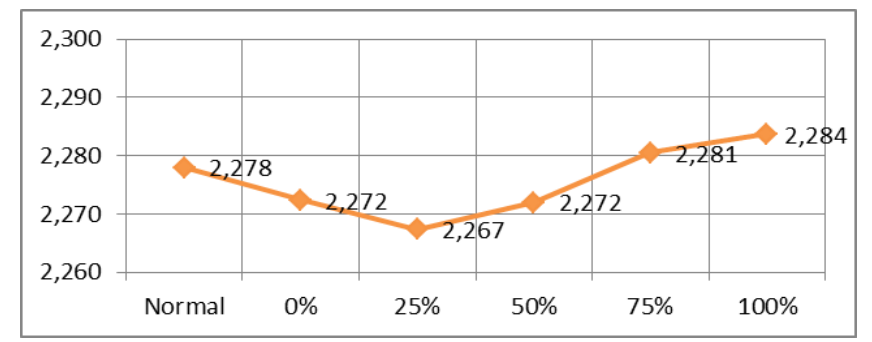

Gambar 1 Pengaruh Kadar Variasi Terhadap Density

Gambar 1 menunjukan hasil pengujian dari nilai density yang didapat pada variasi abu batu karang dan pasir besi sebagai agregat halus $0 \%$ sampai dengan $100 \%$. Penurunan nilai density terjadi pada variasi $0 \%, 25 \%$, dan peningkatan terjadi pada variasi $50 \%, 75 \%, 100 \%$, artinya dengan menambahkan variasi filler abu batu karang dan pasir besi sebagai agregat halus pada jumlah tertentu dapat meningkatkan kerapatan suatu massa pada campuran tersebut. Hal ini disebabkan abu batu karang yang berperan sebagai filler memiliki sifat silika yang cukup tinggi, sehingga dapat mengisi rongga-rongga yang terdapat pada agregat.

\subsection{VMA}

Nilai VMA pada setiap variasi filler untuk campuran normal sebesar $15,949 \%$, variasi $0 \%$ sebesar $15,968 \%$, variasi $25 \%$ sebesar $15,833 \%$, variasi $50 \%$ sebesar $15,981 \%$, variasi $75 \%$ sebesar $15,691 \%$, dan variasi $100 \%$ sebesar $15,573 \%$. Hubungan antara nilai VMA dengan variasi filler dapat dilihat dari turun nya nilai pada variasi $25 \%, 75 \%$, dan $100 \%$, serta peningkatan nilai $V M A$ terjadi pada variasi $0 \%$ dan 50\%. Nilai VMA akan sangat menentukan keawetan (durabilitas) suatu campuran beraspal disamping nilai VIM. Nilai VMA yang diinginkan dalam suatu campuran beraspal adalah seminimum mungkin, hal ini bertujuan agar dapat memberi ruang yang cukup pada aspal untuk dapat melekat dengan baik pada agregat. Nilai VMA yang diperoleh dan hubungan antara nilai $V M A$ dengan variasi filler abu batu karang dan pasir besi sebagai agregat halus dapat dilihat pada Gambar 2.

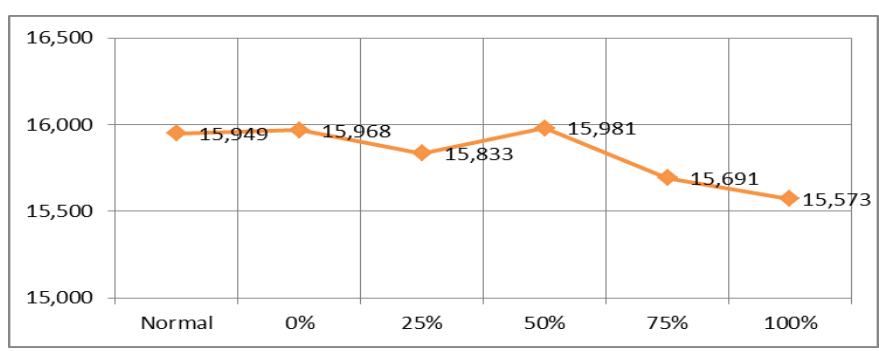

Gambar 2 Pengaruh Kadar Variasi Terhadap VMA

Gambar 2 memperlihatkan bahwa hasil pengujian VMA dengan menggunakan variasi abu batu karang dan pasir besi sebagai agregat halus $0 \%$ dan $50 \%$ mengalami peningkatan dan mengalami penurunan pada nilai $25 \%, 75 \%$ dan $100 \%$. Penurunan secara signifikan terjadi pada kadar abu batu karang dan pasir besi sebagai agregat halus variasi100\% sebanyak 15,573\%, walau begitu semua kadar variasi nilai VMA memenuhi spesifikasi yang disyaratkan Bina Marga (2010) revisi 3 yaitu dengan nilai minimal 14\%, dapat diartikan bahwa pada 
pemberian variasi abu batu karang dan pasir besi $0 \%$ - $100 \%$ pada campuran tersebut meningkatkan nilai VMA sesuai dangan spesifikasi Bina Marga (2010) revisi 3. Hal ini membuat rongga-rongga yang terisi aspal diantara butir-butir agregat masih bisa mengikat secara merata dengan filler yang diberikan, dan filler abu batu karang dan pasir besi sebagai agregat halus 100\% memenuhi VMA.

\subsection{VIM}

Dari hasil pengujian Marshall diperoleh nilai VIM pada setiap variasi untuk campuran normal sebesar 5,430\%, variasi $0 \%$ sebesar $5,136 \%$, variasi $25 \%$ sebesar $5,345 \%$, variasi $50 \%$ sebesar $5,151 \%$, variasi $75 \%$ sebesar $4,759 \%$, dan variasi $100 \%$ sebesar $4,625 \%$. Hubungan antara nilai VIM dengan variasi filler dan agregat halus dapat dilihat dari turun nya nilai $0 \%, 50 \%, 75 \%$, dan $100 \%$, serta peningkatan nilai VIM terjadi pada variasi $25 \%$. Nilai VIM atau void in the mix adalah banyaknya pori diantara butir-butir agregat yang masih tersisa setelah campuran aspal beton AC-BC dipadatkan. Nilai VIM yang diperoleh dan hubungan antara nilai $V M A$ dengan variasi abu batu karang dan pasir besi dapat dilihat pada Gambar 3.

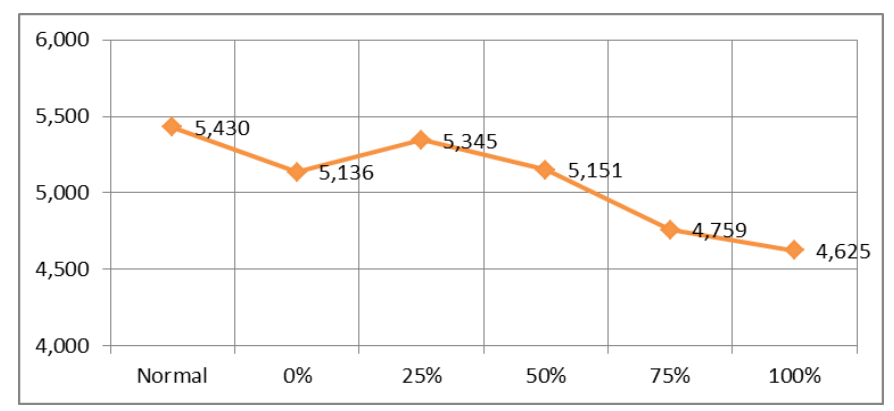

Gambar 3 Pengaruh Kadar Variasi Terhadap VIM

Gambar 3 menunjukan bahwa pengujian VIM dari kadar abu batu karang dan pasir besi meningkat pada nilai variasi $25 \%$, dan terjadi penurunan nilai pada $0 \%, 50 \%, 75 \%$, dan $100 \%$, pada variasi abu batu karang dan pasir besi $0 \%$ turun sekitar 5,136\% naik kembali pada nilai 25\% sekitar 5,345\%, nilai VIM menurun dari $5,345 \%$ sampai $4,625 \%$ yaitu pada variasi $100 \%$, dari pengujian nilai VIM yang telah dilakukan dari variasi abu batu karang dan pasir besi $0 \%$ sampai dengan 100\% masih memenuhi spesifikasi Bina Marga (2010) revisi 3 yaitu dengan nilai VIM 3\% - 5\%, artinya abu batu karang dan pasir besi yang diberikan dengan jumlah tertentu dan hingga mencapai $100 \%$ dapat menyebabkan nilai VIM naik turun dengan nilai yang tak jauh beda dan hanya turun segnifikan pada $100 \%$ dan memenuhi spesifikasi. Hal ini disebabkan sifat abu batu karang yang memiliki permukaan lembut, kesat dan mudah menyatu jika terkena cairan, sehingga dapat terserap pada rongga dalam agregat.

\subsection{VFA}

Dari hasil pengujian Marshall diperoleh nilai VFA untuk campuran normal minimum sebesar $65,368 \%$, variasi $0 \%$ sebesar $68,043 \%$, variasi $25 \%$ sebesar $67,333 \%$, variasi $50 \%$ sebesar $67,925 \%$, variasi $75 \%$ sebesar $69,689 \%$, dan 
variasi $100 \%$ sebesar 70,338\% . Hubungan antara nilai VFA dengan variasi filler dan agregat halus dapat dilihat dari naiknya nilai pada variasi $0 \%$, dan $25 \%, 50 \%$, $75 \%$, dan $100 \%$ dibandingkan dengan nilai normal. Faktor yang mempengaruhi VFA yaitu kadar aspal, gradasi agregat, energi pemadat (jumlah pemadatan), temperatur pemadatan dan absorsi agregat. Grafik hubungan antara kadar filler dan agregat halus dengan nilai VFA dan hubungan antara nilai VFA dengan variasi filler abu batu karang dan pasir besi sebagai agregat halus dapat dilihat pada Gambar 4.

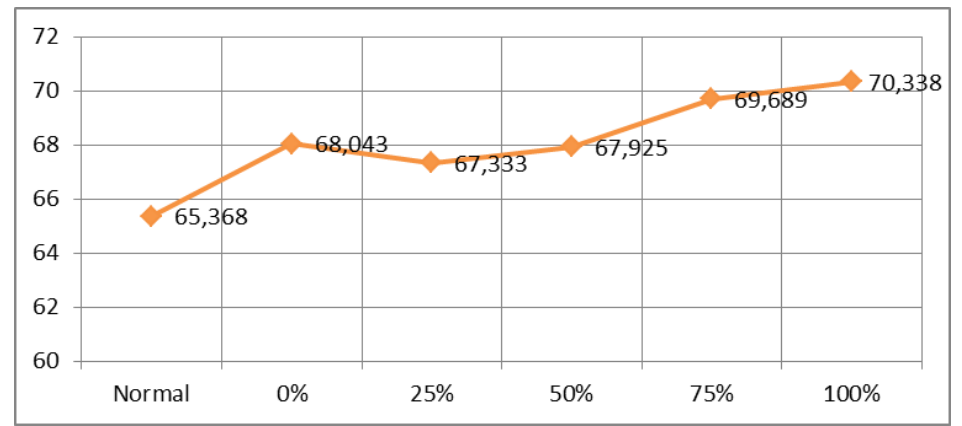

Gambar 4 Pengaruh Kadar Variasi Terhadap VFA

Gambar 4 memperlihatkan bahwa semakin bertambahnya persentase abu batu karang dan pasir besi nilai VFA terus naik. Pada variasi abu abu batu karang dan pasir besi sebagai agregat halus $0 \%-100 \%$ terus mengalami kenaikan, nilai VFA naik sebanyak 70,338\% pada kadar variasi $100 \%$, dan terjadi penurunan pada kadar variasi $25 \%$ dan $50 \%$. Kenaikan secara signifikan terjadi setelah ditambah persentasenya menjadi $75 \%$ - 100\%, artinya dengan penambahan variasi kadar abu batu karang dan pasir besi di atas 50\% dapat meningkatkan nilai VFA. Hal ini disebabkan karena abu batu karang dan pasir besi mengisi rongga-rongga antara agregat kasar dan halus dengan volume yang semakin meningkat, rongga yang terjadi hampir sama pula.

\subsection{Stabilitas}

Dari hasil pengujian Marshall diperoleh nilai stabilitas untuk campuran normal sebesar $1390.91 \mathrm{~kg}$, variasi $0 \%$ sebesar $1368,14 \mathrm{~kg}$, variasi $25 \%$ sebesar $1397,03 \mathrm{~kg}$, variasi $50 \%$ sebesar $1402,06 \mathrm{~kg}$, variasi $75 \%$ sebesar $1419,05 \mathrm{~kg}$, dan variasi $100 \%$ sebesar $1382 \mathrm{~kg}$. Hubungan antara nilai Stabilitas dengan variasi filler dan agregat halus dapat dilihat dari turun nya nilai $0 \%$, dan $100 \%$, dan terjadi peningkatan pada variasi $25 \%, 50 \%$, dan $75 \%$, serta peningkatan nilai Stabilitas tertinggi terjadi pada variasi $75 \%$. Pada perkerasan jalan sangat dituntut untuk memiliki stabilitas yang tinggi. Stabilitas terjadi dari hasil gesekan antar butir dan kemampuan aspal beton mempertahankan ikatannya. Stabilitas merupakan gambaran kemampuan suatu campuran beraspal untuk menerima beban lalu lintas tanpa mengalami perubahan bentuk tetap (deformasi permanen) seperti alur, gelombang ataupun bleeding. Hubungan antara kadar abu vulkanik dengan nilai stabilitas dan hubungan antara nilai Stabilitas dengan variasi filler abu batu karang dan pasir besi sebagai agregat halus dapat dilihat pada Gambar 5 . 


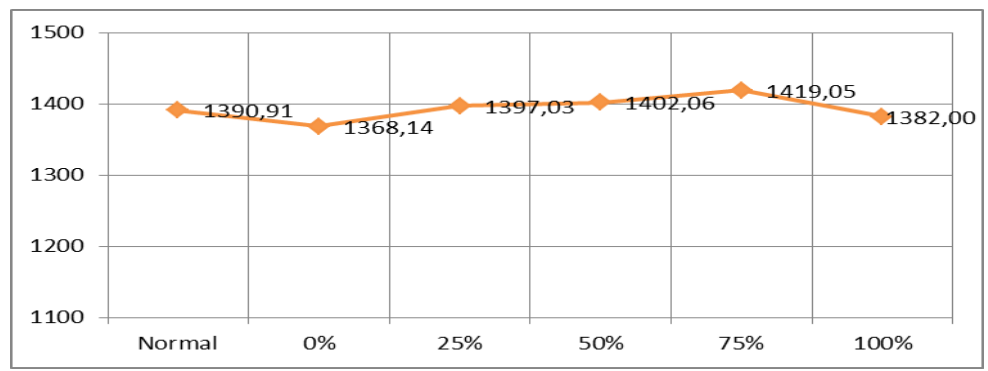

Gambar 5 Pengaruh Kadar Variasi Terhadap Stabilitas

Gambar 5 memperlihatkan bahwa nilai stabilitas mengalami grafik yang naik turun, terlihat pada variasi abu batu karang dan pasir besi $0 \%$ mengalami penurunan pada nilai 1368,14 dan naik di variasi $25 \%$ sampai dengan variasi $75 \%$. Kemudian pada variasi abu batu karang dan pasir besi $100 \%$ mengalami penurunan ke nilai $1382 \mathrm{~kg}$, dapat di artikan bahwa variasi abu batu karang dan pasir besi sebagai agregat halus 0\% sampai dengan 100\% yang diberikan pada campuran tersebut menghasilkan nilai stabilitas yang baik dan memenuhi spesifikasi Bina Marga (2010) revisi 3. Hal ini disebabkan karena kadar abu batu karang dan pasir besi sebagai agregat halus dan aspal yang di gunakan pada campuran relatif baik dan dapat menyelimuti agregat, sehingga kohesi, kerapatan bertambah pada aspal, dan dapat meningkatkan bidang kontak antar agregat.

\subsection{Flow}

Dari hasil pengujian Marshall diperoleh nilai flow pada setiap variasi filler dan agregat halus adalah untuk campuran normal sebesar $3,917 \mathrm{~cm}$, variasi $0 \%$ sebesar 3,567 cm, variasi $25 \%$ sebesar $3,675 \mathrm{~cm}$, variasi $50 \%$ sebesar $3,567 \mathrm{~cm}$, variasi $75 \%$ sebesar $3,417 \mathrm{~cm}$, dan variasi $100 \%$ sebesar $3,233 \mathrm{~cm}$. Hubungan antara nilai Flow dengan variasi filler dan agregat halus dapat dilihat dari turun nya nilai $0 \%, 50 \%, 75 \%, 100 \%$ dan meningkat pada variasi $25 \%$, serta penurunan nilai Flow terendah terjadi pada variasi $100 \%$.

Flow (kelelehan) adalah besarnya deformasi vertikal yang terjadi mulai awal pembebanan sampai kondisi dimana kestabilan menurun. Kelelehan merupakan indikator terhadap kelenturan atau perubahan bentuk plastis campuran beraspal yang diakibatkan oleh beban. Nilai kelelehan (flow) yang diperoleh dan hubungan antara nilai Flow dengan variasi filler abu batu karang dan pasir besi sebagai agregat halus dapat dilihat pada Gambar 6.

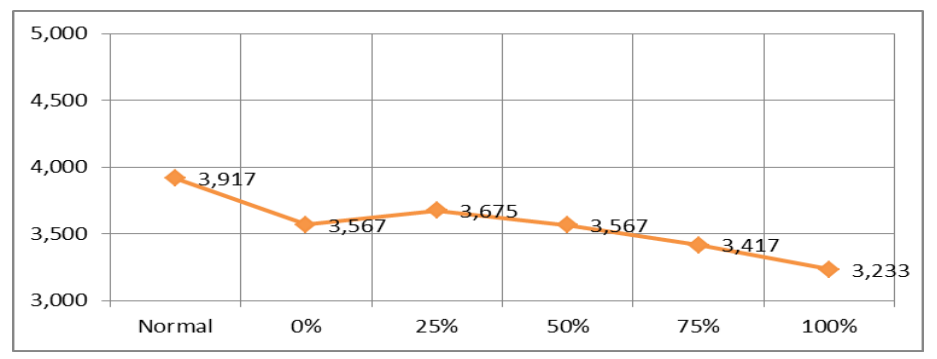

Gambar 6 Pengaruh Kadar Variasi Terhadap Flow

Penggunaan Abu Batu Karang Sebagai Filler Dan Pasir Besi Sebagai Agregat Halus Terhadap Parameter Marshall Pada Campuran Aspal Ac-Bc - Said Jalalul Akbar, 
Gambar 6 memperlihatkan bahwa nilai flow mengalami grafik yang naik turun, hal itu terlihat pada kadar abu batu karang dan pasir besi $0 \%$ mengalami penurunan, dan pada variasi $25 \%$ mengalami kenaikan yaitu dengan nilai flow 3,675 mm. kemudian pada kadar abu batu karang dan pasir besi 50\% sampai $100 \%$ nilai flow turun kembali dari 3,567 mm sampai $3,233 \mathrm{~mm}$, artinya pengaruh pada setiap variasi yang diberikan pada campuran tersebut mulai variasi $0 \%$ sampai $100 \%$ menghasilkan nilai flow yang naik turun. Namun dari pengujian nilai flow yang telah dilakukan dari variasi abu batu karang dan pasir besi $0 \%$ 100\% masih memenuhi spesifikasi Bina Marga (2010) revisi 3, yaitu dengan nilai flow minimal 2,0 - 4,0 mm. Hal ini dikarenakan kadar abu batu karang dan pasir besi sebagai agregat halus yang digunakan pada campuran masih relatif efektif dan cukup sehingga ruang udara dan rongga dalam agregat aspal semakin kecil.

\subsection{Marshall Qoutient (MQ)}

Hasil pengujian Marshall diperoleh nilai MQ pada setiap variasi filler dan pasir agregat halus adalah untuk campuran normal sebesar 445,22 kg/cm, variasi $0 \%$ sebesar $383,80 \mathrm{~kg} / \mathrm{cm}$, variasi $25 \%$ sebesar $436,07 \mathrm{~kg} / \mathrm{cm}$, variasi $50 \%$ sebesar $395,98 \mathrm{~kg} / \mathrm{cm}$, variasi $75 \%$ sebesar $426,88 \mathrm{~kg} / \mathrm{cm}$, dan variasi $100 \%$ sebesar $437,47 \mathrm{~kg} / \mathrm{cm}$. Hubungan antara nilai $M Q$ dengan variasi filler abu batu karang dan pasir besi sebagai agregat halus dapat dilihat dari turun nya nilai $0 \%, 50 \%$, dan meningkat pada variasi $25 \%, 75 \%, 100 \%$, serta peningkatan nilai $M Q$ tertinggi terjadi pada variasi $100 \%$. Nilai MQ diperoleh dari hasil bagi stabilitas dengan kelelehan dan merupakan indikator tingkat kelenturan yang potensial terjadinya keretakan suatu campuran beraspal. Semakin tinggi nilai MQ makan semakin kaku suatu campuran tersebut dan semakin rentan pula terhadap terjadinya keretakan. Nilai MQ yang diperoleh dan hubungan antara nilai Flow dengan variasi filler abu batu karang dan pasir besi sebagai agregat halus dapat dilihat pada Gambar 7.

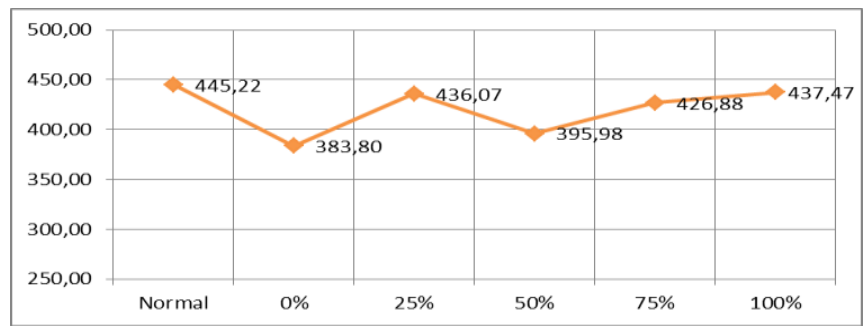

Gambar 7 Pengaruh Kadar Variasi Terhadap MQ

Dari Gambar 7 terlihat bahwa nilai MQ pada variasi abu batu karang dan pasir besi $0 \%$ yaitu sebesar $383,80 \mathrm{~kg} / \mathrm{mm}$ dan meningkat pada variasi abu batu karang dan pasir besi $25 \%$ sebesar $436,07 \mathrm{~kg} / \mathrm{mm}$ dan mengalami penurunan pada $50 \%$ sebesar $395,98 \mathrm{~kg} / \mathrm{mm}$ dan naik sebesar $426,88 \mathrm{~kg} / \mathrm{mm}$ pada variasi abu batu karang dan pasir besi $75 \%$. Pada kadar abu batu karang dan pasir besi $100 \%$ naik menjadi 437,47 kg/mm, turun naik nilai MQ 0\% sampai $100 \%$ dapat diartikan pula bahwa nilai MQ sangat dipengaruhi oleh nilai stabilitas maupun flow. Meskipun nilai MQ mengalami nilai yang turun naik akan tetapi secara umum hasil yang diperoleh menunjukkan bahwa nilai MQ yang diperoleh memenunhi spesifikasi umum 2010 revisi 3 dengan nilai minimum $250 \mathrm{~kg} / \mathrm{mm}$ 


\section{Kesimpulan dan Saran}

\subsection{Kesimpulan}

Berdasarkan hasil penelitian maka dapat diambil beberapa kesimpulan sebagai berikut:

1. Penggunaan abu batu karang sebagai filler dan pasir besi sebagai agregat halus berdampak cukup baik pada aspal beton AC-BC walau tidak menunjukkan pengaruh yang signifikan terhadap benda uji di karenakan nilai stabilitas yang menurun pada kadar variasi $100 \%$.

2. Hasil pengujian pada campuran AC-BC dengan menggunakan material standar menghasilkan nilai kadar aspal optimum (KAO) 6,2\% yang baik.

3. Bahwa nilai, VFA,VIM, stabilitas, dan flow, VMA, MQ mengalami hasil naik turun, dan hasil yang cukup baik terjadi pada kadar variasi $75 \%$, penggunaan abu batu karang sebagai filler dan pasir besi sebagai agregat halus menunjukan seluruh nilai parameter Marshall telah memenuhi Spesifikasi Bina Marga 2010 Revisi 3.

\subsection{Saran}

Berdasarkan hasil pengujian dan penelitian yang telah dilakukan dapat diberikan saran sebagai berikut:

1. Perlu adanya penelitian lanjutan terhadap filler abu karang dengan variasi berbeda dengan campuran lain dan pengujian durabilitas .

2. Diharapkan penelitian penggunaan abu batu karang sebagai filler dan pasir besi sebagai agregat halus dapat ditinjau karakteristik marshall pada lapisan campuran lain seperti AC-WC, dan lain-lain.

3. Keselamatan kerja (K3) setiap proses pengerjaan aspal di Laboratorium sangat di perlukan untuk menunjang keselematan mahasiswa yang diharapkan bisa meminimalisir insiden di tempat penelitian

\section{Daftar Kepustakaan}

Bates, R.L. and Jackson, J.A. (1980) Glassary of Geology. 2nd Edition, American Geological Institute, Virginia.

Hendarsin, S. L., 2000, Perencanaan Teknik Jalan Raya, Politeknik Negeri Bandung, Bandung.

Hardiyatmo, Hary Cristady, 2015, Perancangan Perkerasan Jalan \& Penyelidikan Tanah. Yogyakarta; Gajah Mada University Press.

Kementrian Pekerjaan Umum 2014, Spesifikasi Umum 2010 Revisi 3 Untuk Pekerjaan Konstruksi Jalan dan Jembatan, Dirjen Bina Marga, Jakarta.

Suprapto, 2004, Bahan Dan Struktur Jalan Raya, Teknik Spil, Universitas Gajah Mada

Sukirman, S., 2003, Beton Aspal Campuran Aspal Panas, Granit, Jakarta. Sukirman, S., 1999, Perkerasan Lentur Jalan Raya, Nova, Bandung 